\title{
On the Problems and Recommendations of the Inland Port Container
}

\section{in the Inspection and Quarantine}

\author{
Jian Xu \\ School of management, Shenyang University of Technology \\ No.111,Shen Liao Road(western) \\ Shenyang Economic Technological Development Zone \\ Liaoning 110178,China \\ E-mail:zengfengli8212@sina.com \\ Fengli Zeng \\ School of management, Shenyang University of Technology \\ No.111,Shen Liao Road(western) \\ Shenyang Economic Technological Development Zone \\ Liaoning 110178 ,China \\ E-mail:zengfenglihappiness@126.com
}

\begin{abstract}
Container transport with its high efficiency, convenience, security features becomes an important tool of China Foreign Trade Transportation. Container goods transport is also the main carriers of the inland port international logistics. This article discusses problems and improved measures of the inland port containers in the inspection and quarantine.
\end{abstract}

Keywords: Inland port, Container, Inspection and quarantine

\section{Introduction}

With development of export-oriented economy, the interior realized the import, export and offshore trade. A large number of goods needed to sea by boat, and to sea by boat need ports. Establishment ports in inland equivalent to achieve a shift from the ports to inland port.

Especially for containerized cargo, for inspection in the inland port when exports, then closed by the customs, and pay the transport (trains, cars, ships) of customs supervision shipped to the port, then transit embarkation the sea. If the form of multimodal transport consignments of goods, exports goods made by the carrier in the inland ports and issue bills of lading in local. Exporters clear costs by the bill of lading and then remove the risk of liability. Both of which reduce the hard work and expenditure of the exporters and people of deputy transport from the port, avoiding problems caused by unfamiliar to people, land, business of the port, cutting the risk of responsibility from inland to the port loaded before shipping, but more important is that a bill of lading is received as soon as possible, a guitar back to the purchase price, and speeding up the flow of funds, reduce the psychological burden on delaying the clearing costs of exports of goods.

International container transport is an advanced modern mode of transport, and compared to the traditional grocery casual way, its characteristics are the high efficiency, good economic efficiency and service quality superior. Because of this, container transport develops fast worldwidely, and become an important modernized transport and optimal mode of transport of ensuring international trade for all countries in the world.

However, with the entry-depth inland container transport, cooperative relations of the inland and coastal ports (edge) request enhancement, the importance of the Mainland inspection and quarantine institutions to health quarantine, animal and plant quarantine highlighted. How to improve the understanding of the container inspection and quarantine work, strict, good service, becomes the current problems. 


\section{The problems of the inland port container in the inspection and quarantine}

\subsection{The lack of understanding of the container inspection and quarantine and not enough attention}

Over the past decades, the vast majority of our goods are applicated inspection and passed customs in imported ports. Transiting goods are very little, so container business is minimal and therefore the Mainland inspection and quarantine agencies in the container business, was unable to carry out very well, Have no relevant accumulated experience.

Especially road transport, the difference in time and scattered locations, and transportation companies receiving unit to the container handling time is limited, further increase in overtime costs, although the volume is not large, but worker on the inspection and quarantine to 24 hours Unattended, exhausted. All these circumstances, the Mainland authorities to increase the difficulty of monitoring, time-consuming effort, coupled with insufficient information, thereby relaxing the conduct of the business and management.

\subsection{The lack of coordination mechanism between border crossings and the inland}

(1)There are different procedures between inland ports and border ports, and the lack of mutual exchange of information and feedback result sthat in the inland container ports can not determine whether the health dealt with the fact that the situation there, and caused repeating inspection and missed inspection. Many inland container ports from the port, and some containers are qualified by ports inspection, and empty containers towed inland port loading cargo ship returned to port to export.

(2) "Entry-exit container inspection and quarantine management " require "containers of designated transport locations and clearance, after port entry inspection and quarantine agencies handled application inspection, inspect containers appearance (if necessary, to deal with health pesticides), handle transfer and signed Closure procedures, and transported to notice that inspection and quarantine agencies of designated transport locations, to refer to conduct inspection and quarantine in designated transport locations. "However, the border inspection and quarantine of the container is not in place measures to implement the segregation, some leakages container inspection and quarantine, resulting in the inland container port Identification can not be in place.

\subsection{Legal basis of administrative penalties is not clear}

"People's Republic of China Frontier Health and Quarantine Law" and its "implementation details and the" entry-exit inspection and quarantine management container" made clear: entry-exit containers must implement health quarantine. However, the entry and exit container omitted specific offences, such as defectors seized punishment, "the Regulations" Chapter 11 penalties are not clearly defined penalties to be imposed, resulting in the seizure container inspection and quarantine leakages can not use legal means to deal with and weaken the Inspection and quarantine laws and regulations of deterrence.

\subsection{The follow-up health monitoring pesticide containers troubled inland port inspection and quarantine}

(1)Health pest elimination business on the move most of the phytosanitary, health seizure operations, inland ports lack of health pest elimination methods of technical experts, can not meet the increasing health pesticide business. (2) Treatment of a single health pesticides, chemical spraying, no replacement fumigation pharmaceutical products, health quarantine, effectively moving the phytosanitary not a one-time pest elimination.

\subsection{Difficulties in the scene practical ofcontainer inspection}

(1)Handling locations of container cargo are dispersed widely, and container loading and unloading time can not be identified. The shipper, freight forwarding company handling time, customs clearance time are very nervous. When the containers are transferred to inland ports, consignee and shipper, freight forwarding companies organize working immediately, and even the factory side in the packing of goods, while still short of inland transport. Have no spare the time for container inspection and quarantine generally.

(2)Inspection and quarantine in the implementation of import and export commodities inspection and quarantine and inspection and quarantine of the container while the same can not be carried out, generally to a second inspection and quarantine. The general quality of goods produced in workshops, warehouses within the test. Commodity inspection and quarantine to be qualified, talented people for me shipping crates and containers to the loading point to the exact time can not be determined. So the quality of goods and container inspection and quarantine inspection of the time and place is a great difference, not a one-time completion of the inspection of import and export commodities inspection and quarantine with the container. Oxfam staff in the current seizure less heavy workload of the circumstances, the contradiction between the two very prominent, resulting in the efficiency of container inspection and quarantine lower.

\section{Recommendations of standardized container inspection and quarantine work}

\subsection{High level of awareness of the importance of the container inspection and quarantine work}

Containers are the major spread carriers of all kinds of vector insects, rodents, toxic and harmful substances, bearing on China's agriculture, forestry, animal husbandry and people's life and safety. Over the years, most of the work from 
coastal areas (edge) ports commitment to inland ports have been established in recent years, the corresponding work should also play. Inland ports are actually relatively coastal (edge) ports, the port is the concept of location, its function and responsibility of the coastal and (while) at basically are the same. Inland ports should attach great importance to the work, understand the danger of invasion of the disease.

\subsection{Acting in accordance with the law, the seizure in accordance with the standard application}

Inspection and quarantine "Three Methods", "three ordinances" have corresponding provisions to container inspection and quarantine of a, inspection and quarantine standards in the industry have "SN/T1102-2002 immigration container inspection and quarantine protocols", "N/T0982-2000 security and the import and export containers Health examination of order "and other standards, and all six standards are developed for container . From a legal point of view or from their own responsibilities speaking, the Mainland authorities should strictly abide by the laws and regulations, a sense of responsibility, to seriously implement the "methods", earnestly carry out their duties.

\subsection{Exchange of information, coordination and cooperation with the border ports}

In accordance with the "fast clearance", the boundary crossing points, customs clearance speed more quickly, entry and exit inspection and quarantine agencies at the scene in accordance with the standard requirements of pumping me identification is impossible, container inspection and quarantine inspection should be transferred out to other places Can be effectively checked. Immigration control points on the border transit of container inspection and quarantine, as required to ensure segregation, the information transmitted to the work of inland ports, inland ports and border crossings to close collaboration, strengthening information communication and timely feedback inspection and quarantine issues.

\subsection{Tthe entry-exit inspection and quarantine implementation of the Container dynamic classification management}

\section{(1) Category management for imported container}

Grasp, the collection of human infectious diseases, animal and plant pests and pest outbreaks, the establishment of imported container inspection and quarantine database of area businesses imported goods, the type and quantity of packaging carefully mapping, with its declaration and the integrity of a comprehensive analysis and possible quarantine risk assessment, inspection and quarantine identified key. On imported goods and containers and related enterprises, classification and quarantine management, the container and its cargo quarantine risk factor has a small, fast issued in advance.

\section{(2) classification managemen for the containert}

Of the larger freight forwarding companies, container station, and foreign trade companies from the container dynamic classification management, inspection and quarantine institutions to work with day-to-day sampling of regular or irregular conduct the inspection and appraisal, inspection and quarantine agencies for the implementation of classified management of containers Business-related staff in professional training, the training of qualified job evaluation task commitment, Inspection and Quarantine, the enterprise must be carried out by inspection and quarantine requirements of some basic public health work, if we find that the container in question should be timely written report. Some of preventive pre-inspection and quarantine to enterprises to complete, so can better solve the heavy workload and the relative lack of power of inspection and quarantine issues, can change the situation that the inspection and quarantine institutions to each batch seized but not seized, and could not be recognized inspection and quarantine.

\subsection{Strengthen the construction of sanitation units of inland ports}

(1) Increase the health of inland ports pesticides technical team-building, non-organized business training courses, health pesticides to deal with the workload increased year by year the situation, found that the epidemic will be able to meet the fastest rate of pesticide health requirements.

(2)Strengthening health pest elimination of scientific research, as soon as possible to research and development of high efficiency, low cost, convenient, fast and safe method of fumigation of drugs and pesticides to meet one-time deal with the requirements of Health and pesticides.

\subsection{Improve work methods, improve service quality, lower trading costs}

Container is devided into empty and full. In accordance with the regulations, full containers are taken implementation inspection and quarantine together with the cargo. The Immigration containers, the inland port can be completed independent inspection departments, the container exit inspection and quarantine, should be realistic, goods seized by the department together with the cargo inspection and quarantine, or verify "container inspection and quarantine Results", "inspection and quarantine fumigation / disinfection Certificate ", released at verification. Thus, on the one hand inspection and quarantine institutions can play the role of various departments, saving a lot of manpower, material, on the other hand can save valuable time logistics, to monitor the scientific, standardized and effective, raise work efficiency. In addition, should take a variety of methods to strengthen the inspection teams of professional training and improve job skills and professional ethics, change our work style, enhance service awareness, improve service quality, 
implementation of the reservation system of work for eight hours, shortening the clearance cycle, thus reducing costs , User-friendly.

\section{7 landlocked inspection and quarantine agencies provide good advice and problem-solving}

Environment for application test units andthe application test worker. Prosecution of the business sector has released ID cards to registered application inspection members, Rapporteur on the implementation of identification to application inspection members, and trurely realized application inspection by certificate. Port inspection and quarantine law enforcement worker found the illegal business in the identification process , and should report departments on a timely. Take punishment and a combination of education to norm the acts of application inspection. Establish integrity of agent market of application inspection. To sum up, land crossings, Inspection and Quarantine to strengthen internal management and the building of the contingent, to ensure full implementation of functions at the same time the strengthening of external communication and cooperation, give full play to the functions of economic development services.

\section{Conclusions}

Based on discussing problems and improve the measures of the inland container port inspection and quarantine work, strengthen the inland container port management, speed up customs clearance, reduce the losses brought by inspection and quarantine.

\section{References}

Gao Caiyun. Commodity inspection practices. Machinery Industry Press .2006.12:234-245.

Ni Zhaoyong, Qian Yanyun, Shen Xiangde. The land crossings to China International Logistics Center mode of operation. Conservation and storage and transportation of goods .2004,6 (3): 1- 6.

Qi Ershi. Tianjin port container inspection and quarantine management. Containerized. 2005,3:12-15.

Zou Quansheng. "WTO accession" to the international logistics industry challenges and the corresponding [J]. Economist .2002:35-45. 